\title{
Mechanisms Linking Heat Stress to Poor Reproductive Performance of Nigerian Indigenous Zebu Cows
}

\author{
Wachida Ndumari ${ }^{1}$, Philip Makama Dawuda ${ }^{1}$, Iyorhemba Utim Ate ${ }^{1}$ and \\ Peter Ibrahim Rekwot ${ }^{2}$
}

${ }^{1}$ Federal University of Agriculture, College of Veterinary Medicine, Department of Theriogenology P.M.B.2373 Makurdi, Benue State, Nigeria

${ }^{2}$ National Animal Production Research Institute (NAPRI) Shika, Ahmadu Bello University Zaria, Kaduna State, Nigeria

*Corresponding author: ndumariwachida@mail.com

Received: 10-09-2020

Revised: 24-11-2020

Accepted: $13-12-2020$

\begin{abstract}
Study was conducted to evaluate how heat stress affects follicular size, reproductive hormones, oestrus expression in different seasons. Twelve $(n=12)$ zebu cows were utilized over a year. Ambient temperature, relative humidity was collected and THI value determined, rectal temperatures were also collected. Cows were synchronized for oestrus. Ultrasonic follicular studies were carried out until ovulation. Blood was collected to assayserum concentration of progesterone, oestradiol and Luteinizing hormones using Enzyme-Linked Immunosorbent Assay technique. Oestrus activities were monitored; follicular diameters at $42 \mathrm{hr}$ were shorter $P<0.05$ in cold dry season than hot dry and raining season. At $72 \mathrm{hr}$ follicular diameters were longer $P<0.05$ in hot dry season than cold dry and raining season. Time to peak of oestradiol was shorter $P<0.05$ in cold dry season than hot dry and raining seasons. Amplitude of oestradiol was higher $P<0.05$ in cold dry season than hot dry and raining seasons. Time to peak of LH surge was shorter $P<$ 0.05 in cold dry season, than hot dry and raining season. Amplitude of LH surge was higher $P<0.05$ in raining season than cold dry and hot dry season. Duration of LH surge was longer $P<0.05$ in cold dry season, than hot dry and raining season. Mounting was higher $P<0.05$ in cold dry season than raining and hot dry season. Conclusion: Heat stress has increased follicular size without increasing oestradiol concentration, reduced mounting, increased LH surge and progesterone concentration.
\end{abstract}

Keywords: Hormones, seasons, heat stress, zebu cows

The ambient temperature associated with infertility in cattle has drawn the attention of researchers all over the world (Armstrong, 1994). Several environmental factors play a crucial role in maintaining the reproductive function of the dairy cow (Nabenishi et al. 2011). Among these factors, heat stress has been identified to be the critical cause of infertility in dairy cattle (Nabenishi et al. 2011). Highly productive cattle are more susceptible to the change in the environment which is manifested as altered sexual cyclicity as well as the ovarian activity (Alves et al. 2014).

Cattle that are directly exposed to heat stress during summer season experience low fertility which is one of the constraints faced by farmers throughout the world (Lopez, 2003). This persisting effect of summer heat on fertility of cows results in altering the development of pre-ovulatory follicles during severe hot months (Wakayo et al. 2015). Even minor alterations in the core body temperature were established to be sensitive enough to induce changes in the oestrous cyclicity in dairy cows (Roth et al. 2001a). The altered oestrous cycle behaviour

\footnotetext{
How to cite this article: Ndumari, W., Dawuda, P.M., Ate, I.U. and Rekwot, P.I. (2020). Mechanisms Linking Heat Stress to Poor Reproductive Performance of Nigerian Indigenous Zebucows. Theriogenology Insight: An International Journal of Reproduction of Animals, 10(3): 83-92.
}

Source of Support: TET; Conflict of Interest: None 
of cows exposed to heat stress results in late manifestation of oestrus and a lengthened oestrus interval which leads to a high incidence of silent oestrus/anovulation and anoestrus in dairy cows (Fisher et al. 2008).

Sexual behavior peculiarities of Zebu breed of animals, such as short length of oestrus and reduced mounting activity can lead to errors in oestrus detection (Piccione et al. 2003). Zakari et al. (1981) observed that intensity of oestrus behavior increased during the hottest months of the year and Galina et al. (1995) suggested that winter could limit the expression of oestrus in Zebu cows. Plasse et al. (1981) observed a high occurrence of long oestrous cycles and silent oestrus/anovulations during the winter, and Zakari et al. (1981) verified the occurrence of longer oestrous cycles in the pre-raining season than in the raining season in Zebu cows. Studies on oestrus behavior in Zebu cows can be made easier by oestrus synchronization. However, evidence suggests that the pharmacological agents utilized in synchronization can alter some animal oestrus behavioral characteristics, such as oestrus length (Plasse et al. 1981) and intensity (Orihaela et al. 1983).

Reproductive studies in Nigerian indigenous Zebu cowsby workers (Orituela et al. 1983; Dawuda et al. 1988; Pathiraja et al. 1988 and VohJr et al. 1989) have indicated poor reproductive performance of these Zebu cows. Knowledge of the mechanism(s) that are involved in causing this poor reproductive performance in our indigenous cattle will afford us with the opportunity to proffer solutions in solving the problem of infertility in these breeds of cattle.

It was therefore, hypothesized that there would be effect of environmental heat stress on the follicle size, profiles of reproductive hormones and oestrus expression in the indigenous cattle breeds. To test this hypothesis, the objectives of the current study were to evaluate the effects of heat stress on (i) follicle size (ii)reproductive hormones and(iii) oestrus expression.

\section{MATERIALS AND METHODS}

\section{Study location}

The study was conducted at the Veterinary Teaching Hospital Research Station, South Core, Federal University of Agriculture Makurdi Benue State,
Nigeria. Makurdi is situated in the Southern Guinea Savannah, 600 metres above sea level on latitude $7^{\circ}$ $14^{\prime}$ North and longitude $8^{\circ} 21^{\prime}$ East. The area has a warm temperatures ranging from 24 to $40{ }^{\circ} \mathrm{C}$, with relatively greater temperatures occurring between March and May, the average rainfall is between 508 and 1016mm annually (Timi and Tor, 2016).

\section{Determination of temperature humidity index (THI)}

A year period of weather data (Ambient temperature and Relative humidity) were collected from the Air Force Base Weather Station located 2 kilometers away from the research station. The temperature humidity index (THI) was calculated for the three seasons using the formula developed by (Kible, 1964). It is as follows:

$$
T H I=1.8 * T a-(1-H R) *(T a-14.3)+32
$$

Where: $\mathrm{Ta}=$ Mean Ambient Temperature in ${ }^{\circ} \mathrm{C}$; $H R$ = Mean Relative Humidity. The determined THI values were used to identify heat stress seasons in Makurdi and to examine the seasonal variation of THI.

\section{Determination of Heat Stress base on THI values}

Heat stress determined in zebu cows by Du Preez (2000) was adopted, THI value $\leq 74$ is a thermal zone for zebu cattle, temperature humidity index (THI) values; (75-86) heat stress.

\section{Experimental animals and management}

The research was carried out with the approval of the Ethical Committee of the College of Veterinary Medicine, Federal University of Agriculture Makurdi, Nigeria. Twelve $(n=12)$ matured, cycling, non-pregnant zebu cows with history of 2-3 successful calving, average weight of $338.92 \pm$ $16.39 \mathrm{~kg}$ and body condition scores of $3.68 \pm 0.13$ on a scale of 5 , were utilized over 3 replicate months (November-February, March-May and June-October). These breeds of cows were selected because they are widely distributed across the country in dense population. The cows were identified with the use of large plastic ear tags and kept for a 6 months period of stabilization, during which blood and fecal samples were 
collected to screen for parasites and treatment was instituted accordingly. Pregnancy examination using transrectal ultrasonography was carried out to ensure the cows were not pregnant. The cows were managed under semi-intensive management system by grazing them in the morning and supplemented with concentrate diet at $3 \%$ of their body weight in the evening. The concentrate consisted of cotton seed cake; maize and wheat bran in the ratio 1:2:4. Mineral salt licks and clean drinking water were provided ad-libitum.

\section{Experimental Design}

Repeated measure and randomized design model were used;this study was divided into three phases:

Phase I: November-February (cold dry season)

Phase II: March - May (hot dry season)

Phase III: June - October (raining season)

\section{Monitoring of rectal temperature}

Rectal temperature was monitored twice a week with the use of clinical thermometer between 12:00 PM -1:00 PM throughout the experiment period.

\section{Oestrus synchronization}

At the end of each phase,cows were synchronized foroestrus using $\mathrm{PGF}_{2} \alpha$ (Synchromate that contained Cloprostenol manufactured by Bremer Pharma Gmbh 34414 Warburg Germany Batch No. 26176) at $(500 \mu \mathrm{g}) /$ cow intramuscularly. Two injections were administered 12 days apart.

\section{Monitoring of oestrus activity}

Oestrus was monitored $48 \mathrm{hr}$ after administration of second dose of $\mathrm{PGF}_{2} \alpha$ by visual observation of animals for signs of oestrus such as mounting, vaginal mucous discharge and hyperemia of the vulva for $2 \mathrm{hr}$ at each occasion twice daily between 06:0008:00 AM and 04:00-06:00 PM, to determine oestrus intensity and duration. Oestrus intensity was the number of times the cows mounted other cows or stood to be mounted by other cows and oestrus duration was the length of time the cow was in oestrus.

\section{Scoring of oestrus activities}

Oestrus activities were scored using the methodology described by (Dupreez et al. 1990).

\section{Follicular study}

Ultrasonic follicular studies measuring the size of the largest follicles in first follicular wave using a real time B-mode Ultrasound scanner (manufactured by Edan Instrument Inc. 1019// Skeko Nashan Shenzhen 518067PR China with transrectal probe of $7.5 \mathrm{MHz}$ linear array) was carried out ransrectally daily 24 hr after administration of second dose of $\mathrm{PGF}_{2} \alpha$ until ovulation occurs. Occurrence of ovulation was considered as the presence of ovulation depression fossa. All cows ovulated with $18 \mathrm{hr}$.

\section{Blood Sample collection}

Blood sample for E2 assay commenced $24 \mathrm{hr}$ after administration of second dose of $\mathrm{PGF}_{2} \alpha$. Two (2) ml of blood samples through the indwelling catheter in the jugular vein were taken into a sample bottle without Ethylenediaaminetetraacitic acid (EDTA) to harvest sera at every $6 \mathrm{hr}$ for $72 \mathrm{hr}$ for oestradiol determination. Blood sample collection for $\mathrm{LH}$ also commenced $48 \mathrm{hr}$ after administration of second dose of $\mathrm{PGF}_{2} \alpha$ at the interval of every $2 \mathrm{hr}$ for $72 \mathrm{hr}$ for LH determination. Blood sample was collected twice a week for a period of 12 months for progesterone determination. Blood samples collected were kept at room temperature for $30 \mathrm{~min}$ and spun using centrifuge model 80-2 Lemfield Medical England at $3000 \mathrm{rpm}$ for $15 \mathrm{sec}$ and serum samples were harvested and stored at $-20{ }^{\circ} \mathrm{C}$ until analysis.

\section{Serum Hormonal assay}

Progesterone, oestradiol and luteinizing hormones assay were carried out using Enzyme-Linked Immunosorbent Assay (ELISA) Kits (AccuBind, USA) according to the manufacturer instructions and ELISA Reader (Thermo Scientific Multi task an EX (Vantaa Find land) was used in this study.

Assays were validated using the absorbance (OD) of the calibrators for each hormone according to the manufacturer instruction. Inter- assay \% CV was 14.5 and intra-assay \% CVs 8.1. For progesterone, Inter- assay \% CV was 12.5 and intra-assay \% CVs 5.6 for oestradiol, and Inter- assay \% CV was 13.6 and intra-assay \% CVs 7.2 for LH. 


\section{Determination of Serum Proestrus Oestradiol $\left(E_{2}\right)$ Surge}

The proestrusoestradiol $\left(E_{2}\right)$ profile were used to determine the serum proestrus $\mathrm{E}_{2}$ amplitude (concentration), area under the $\mathrm{E}_{2}$ secretion curve (duration), and time to $\mathrm{E}_{2}$. Peak (area before curve). Proestrus $\mathrm{E}_{2}$ surge was considered to have occurred if $E_{2}$ concentration in one of the thirty six consecutive six hourly serum samples was equal to or above 10 $\mathrm{pg} / \mathrm{ml}$ following synchronized oestrus. This value was chosen because in all the animals that showed overt oestrus this value was the lowest elevated serum $\mathrm{E}_{2}$ value $24 \mathrm{hr}$ after synchronized oestrus. An $E_{2}$ surge was present irrespective of the peak values once it had exceeded $10 \mathrm{pg} / \mathrm{mL}$ following oestrus synchronization.

\section{Determination of Serum Pre-ovulatory Luteinizing Hormone (LH) Surge}

Serum pre-ovulatory luteinizing hormone (LH) profile were used to determine the LH surge characteristics, LH amplitude (concentration), duration of LH (area under the curve), and time to LH peak (area before curve). Preovulatory LH surge was considered to have occurred if LH concentration in one of the thirty six consecutive two hourly serum samples was equal to or above 2 $\mathrm{ng} / \mathrm{ml}$ following synchronized oestrus. This value was chosen because in all the animals that had elevated LH concentration; this value was the lowest elevated serum LH value $24 \mathrm{hr}$ after synchronized oestrus. An LH surge was present irrespective of the peak values once it had exceeded $2 \mathrm{ng} / \mathrm{L}$ following oestrus synchronization.

Data for rectal temperature, progesterone, follicular diameters, surge characteristics for proestrusoestradiol surges and preovulatoryluteinizig hormone surges (time to peak, amplitude and duration)were analyzed by repeated measure ANOVA using R Studio (R Core Team 2019). Tukey's Honesty Significant Difference Test was applied to determine significant difference among the groups at $P<0.05$.

\section{RESULTS AND DISCUSSION}

\section{Temperature humidity index (THI)}

Temperature humidity index (THI) values for the weather station were 45 in cold dry season, 93.4 in hot dry season and 93 in raining season respectively, Table 1. This result showed that zebu cows were not under heat stress in cold dry season. However, the THI values in hot dry and raining season showed that the cows were underheat stress.

Table 1: Ambient Temperature, Relative Humidity and Temperature Humidity Index values during cold dry, hot dry and rainy season

\begin{tabular}{|llll|}
\hline Season & $\begin{array}{l}\text { Average } \\
\text { Ambient } \\
\text { Temperature }\left({ }^{\circ} \mathrm{C}\right)\end{array}$ & $\begin{array}{l}\text { Average } \\
\text { Relative } \\
\text { Humidity (\%) }\end{array}$ & THI \\
\hline Cold dry & 35.8 & 45.8 & 45.0 \\
Hot dry & 37.5 & 65.0 & 93.4 \\
Rainy & 31.6 & 76.6 & 93.0 \\
\hline
\end{tabular}

THI = Temperature Humidity index.

Cows rectal temperature during the cold dry, hot dry and raining season

The rectal temperatures were significantly higher $P<0.05$; in hot dry season $\left(38.07 \pm 0.03^{\circ} \mathrm{C}\right.$ and raining season $38.06 \pm 0.03{ }^{\circ} \mathrm{C}$ respectively) than cold dry season (37.71 $\pm 0.04{ }^{\circ} \mathrm{C}$; Table 2). There were no significant difference $\mathrm{P}>0.05$ between hot dry and raining seasons.

Table 2: Rectal temperatures of zebu Cows in cold dry, hot dry and rainy season

\begin{tabular}{lll}
\hline Season & Months & $\mathbf{T}^{\circ} \mathbf{C}$ \\
\hline Cold dry & 4 & $37.71 \pm 0.04^{\mathrm{b}}$ \\
Hot dry & 3 & $38.07 \pm 0.03^{\mathrm{a}}$ \\
Rainy & 5 & $38.06 \pm 0.03^{\mathrm{a}}$ \\
\hline
\end{tabular}

Keys: $n=$ No of cows

$a=$ significantly higher $(P<0.05)$ along the column.

$b=$ significantly lower $(P<0$.05)along the column.

\section{Effect of heat stress on serum progesterone concentration}

Serum progesterone concentration was significantly lower $P<0.05$ in cold dry season $(1.096 \pm 0.075$ $\mathrm{ng} / \mathrm{ml})$ than hot dry $(1.408 \pm 0.90 \mathrm{ng} / \mathrm{ml})$ and raining seasons $(1.361 \pm 0.86 \mathrm{ng} / \mathrm{ml}$, respectively; Table 3$)$. There were no significant difference $P>0.05$ between hot dry and raining seasons. This observation was consistent with the findings of (Rosenberg et al. 1977; Younas et al. 1993 and Ronchi et al. 2001) who reported that heat stress 
increases plasma progesterone concentrations. However was inconsistent with the findings of (Wilson et al. 1998; Roth et al. 2000; Guzeloglu et al. 2001) who reported that heat stress has no effect on the plasma progesterone concentrations during summer heat stress in dairy cows. These differences in progesterone concentrations could be due to breed difference and climatic condition in which the research was carried out.

Table 3: Serum Progesterone Concentrations of Bunaji and Bokoloji Cows Durig Cold Dry, Hot Dry and Raining Seasons

\begin{tabular}{lll}
\hline Season & Months & $\begin{array}{l}\text { Plasma } \mathbf{P}_{4} \text { concentration } \\
(\mathbf{n g} / \mathbf{m l})\end{array}$ \\
\hline Cold dry & 4 & $1.096 \pm 0.08^{\mathrm{b}}$ \\
Hot dry & 3 & $1.408 \pm 0.90^{\mathrm{a}}$ \\
Raining & 5 & $1.361 \pm 0.86^{\mathrm{a}}$ \\
\hline
\end{tabular}

Keys: $n=$ number of cows

$a=$ significantly higher $(P<0.05)$ along the column

$b=$ significantly lower $(P<0.05)$ along the column

\section{Follicular dimensions}

Follicular diameters at $24 \mathrm{hr}$ after administration of second dose of $\mathrm{PGF}_{2 \alpha^{\prime}}$ were significantly longer $P<0.05$ in raining season $(8.62 \pm 0.9 \mathrm{~mm})$ followed by hot dry season $(8.09 \pm 0.52 \mathrm{~mm})$ and then cold dry season $(6.34 \pm 0.68 \mathrm{~mm})$. There were no significant differences $P>0.05$ between hot dry season (8.09 $\pm 0.52 \mathrm{~mm})$ and raining season $(8.62 \pm 0.92 \mathrm{~mm})$, Table 4 . At $48 \mathrm{hr}$, after administration of second dose of $\mathrm{PGF}_{2 \alpha^{\prime}}$ follicular diameters were significantly longer $p<0.05$ in hot dry $(10.75 \pm 0.73 \mathrm{~mm})$ followed by raining season $(9.66 \pm 0.92 \mathrm{~mm})$ and then cold dry season $(9.01 \pm 0.45 \mathrm{~mm})$; but did not differed significantly $P>0.05$ between hot dry $(10.75 \pm 0.73$ $\mathrm{mm})$ and raining season $(9.66 \pm 0.92 \mathrm{~mm})$. At $72 \mathrm{hr}$ after administration of second dose of $\mathrm{PGF}_{2 \alpha}$ follicular diameters were significantly longer $p<0.05$ in hot dry season $(17.01 \pm 1.41 \mathrm{~mm})$ followed by cold dry season $(12.90 \pm 1.22 \mathrm{~mm})$ and then raining season $(12.08 \pm 0.82 \mathrm{~mm})$. There were no significant differences $p>0.05$ between cold dry $(12.90 \pm 1.22$ $\mathrm{mm}$ )and raining season $(12.08 \pm 0.82 \mathrm{~mm})$. Also, the follicular diameters were significantly longer $p<0.05$ at $72 \mathrm{hr}(12.08 \pm 0.82 \mathrm{~mm})$ followed by at 48 $\mathrm{hr}(9.01 \pm 0.45 \mathrm{~mm})$ and then at $24 \mathrm{hr}(6.34 \pm 0.68$ $\mathrm{mm}$ ) respectively. This observation corroborates the findings of (Bajagai, 2011; De Rensis et al. 2002) who

Online ISSN: 2277-3371 reported that heat stress increases follicular size. However, it was inconsistent with the observation of (Shehab-El-Dean et al. 2010), who reported that heat stress decreases the diameter of follicles and induces biochemical changes in the follicular fluid. It is worth noting, however, that follicular size is not a good indicator of functional follicular dominance (Forttune et al. 1991). The follicles can be big for nothing if it lacks $\mathrm{LH}$ receptors that can trigger ovulation.

Table 4: Follicular diameter of zebu cows at 24, 48 and $72 \mathrm{hr}$ after administration of second dose of

$$
\mathrm{PGF}_{2 \alpha}
$$

\begin{tabular}{llll}
\hline \multicolumn{3}{c}{ Follicular Diameters $(\mathrm{mm})$} \\
\hline $\begin{array}{l}\text { Time } \\
\text { (hr) }\end{array}$ & $\begin{array}{l}\text { Cold dry season } \\
\mathbf{n}=\mathbf{1 2}\end{array}$ & $\begin{array}{l}\text { Hot dry } \\
\text { season } \\
\mathbf{n}=\mathbf{1 2}\end{array}$ & $\begin{array}{l}\text { Raining } \\
\text { Season } \\
\mathbf{n}=12\end{array}$ \\
\hline 24 & $6.34 \pm 0.68^{\mathrm{bd}}$ & $8.09 \pm 0.52^{\mathrm{bc}}$ & $8.62 \pm 0.92^{\mathrm{bc}}$ \\
48 & $9.01 \pm 0.45^{\mathrm{ad}}$ & $10.75 \pm 0.73^{\mathrm{ac}}$ & $9.66 \pm 0.92^{\mathrm{bc}}$ \\
72 & $12.09 \pm 1.22^{\mathrm{ad}}$ & $17.01 \pm 1.41^{\mathrm{ac}}$ & $12.08 \pm 0.82^{\mathrm{bd}}$ \\
\hline
\end{tabular}

Keys: $n=$ No of cows,

$a=$ significantly higher $(P<0.05)$ along the column

$b=$ significantly lower $(P<0.05)$ along the column

$c=$ significantly higher $(P<0.05)$ across the row

$d=$ significantly lower $(P<0.05)$ across the row

\section{Characteristics of proestrusoestradiol surge}

The time to peak of serum proestrusoestradiol surges were significantly longer $P<0.05$ in raining season followed by hot dry season $(35.42 \pm 4.25 \mathrm{hr})$ and then cold dry season $(31.50 \pm 5.41 \mathrm{hr})$ respectively, Table 5. The amplitude of proestrusoestradiol surges were significantly higher $P<0.05$ in cold dry season $(39.13 \pm 5.27 \mathrm{pg} / \mathrm{mL})$ followed by hot dry season $(19.50 \pm 2.52 \mathrm{pg} / \mathrm{mL})$ and then raining season $(17.63$ $\pm 1.89 \mathrm{pg} / \mathrm{mL})$. Duration of proestrus $\mathrm{E}_{2}$ surges were significantly longer $p<0.05 \mathrm{in}$ raining season $(40.88 \pm 7.10 \mathrm{hr})$ followed by hot dry season (35.50 $\pm 7.71 \mathrm{hr})$ and then cold dry season $(24.25 \pm 3.27$ $\mathrm{hr})$, respectively. Which corroborates the findings of (Wilson et al. 1998; Khan et al. 2020) who reported that plasma oestradiol concentration was reduced by heat stress in dairy cows. Also, (Roth et al. 2000) reported that reduction in the steroidogenic capacity of follicles under thermal stress is characterized by less aromatase activity of granulosa cells and decreased oestradiol concentration in the 
dominant follicle. An effect that is consistent with decreased concentrations of $\mathrm{LH}$ and reduced dominance of the selected follicles (Roth et al. 2000). Potentially, adverse effects of low oestradiol production may lead to impaired oestrus duration and intensity; suppression of LH surge which, in turn, might impair events associated with ovulation; enhancement of the development of ovarian cysts; and alteration of corpus luteum development that affects progesterone production (Wilfenson et al. 2000). The time to peak and duration of proestrusoestradiol surge were increased by environmental heat stress, the reason for this increase was not clear.

Table 5: Characteristics of proestrusoestradiol surge of zebu cows in cold dry, hot dry and raining season

\begin{tabular}{lllll}
\hline Season & $\mathrm{N}$ & $\begin{array}{l}\text { Time to peak } \\
\text { of } \mathrm{E}_{2} \text { surge } \\
(\mathbf{h r})\end{array}$ & $\begin{array}{l}\text { Amplitude of } \\
\mathrm{E}_{2} \text { surge }(\mathrm{pg} / \\
\mathrm{mL})\end{array}$ & $\begin{array}{l}\text { Duration of } \\
\mathrm{E}_{2} \text { surge (hr) }\end{array}$ \\
\hline Cold dry 12 & $31.50 \pm 5.41^{\text {ad }}$ & $39.13 \pm 5.27^{\mathrm{ac}}$ & $24.25 \pm 3.27^{\mathrm{bd}}$ \\
Hot dry & 12 & $35.42 \pm 4.25^{\mathrm{ac}}$ & $19.50 \pm 2.52^{\mathrm{bd}}$ & $35.50 \pm 7.71^{\text {ac }}$ \\
Raining & 12 & $52.25 \pm 7.08^{\mathrm{ac}}$ & $17.63 \pm \mathrm{i} .89^{\mathrm{bd}}$ & $40 . .88 \pm 7.10^{\mathrm{ac}}$ \\
\hline
\end{tabular}

Keys: $n=$ No of cows

$a=$ significantly higher $(P<0.05)$ along the row

$b=$ significantly lower $(P<0.05)$ along the row

$c=$ significantly higher $(P<0.05)$ along the column

$d=$ significantly lower $(P<0.05)$ along the column

\section{Characteristics of pre ovulatory LH surge}

The time to peak of serum pre-ovulatory LH surges were significantly earlier $P<0.05$ in cold dry season $(38.38 \pm 2.29 \mathrm{hr})$, followed by hot dry season $(44.40$ $\pm 4.76 \mathrm{hr})$ and then raining season; $(53.86 \pm 5.37 \mathrm{hr})$, Table 6. The amplitude of pre-ovulatory LH surges were significantly higher $P<0.05$ in raining season $(11.8 \pm 4.59 \mathrm{ng} / \mathrm{mL})$, followed by hot dry season $(4.18 \pm 0.86 \mathrm{ng} / \mathrm{mL})$ and then cold dry season $(4.14$ $\pm 0.3 \mathrm{ng} / \mathrm{mL})$. There was no significant difference $P>0.05$ between hot dry season $(4.18 \pm 0.86 \mathrm{ng} / \mathrm{mL})$ and cold dry $(4.14 \pm 0.3 \mathrm{ng} / \mathrm{ml})$. Which corroborates the findings of (Gilad et al. 1993) who reported decrease in LH pulse amplitude during heat stress in heifers. The current finding however, disagreed with those of Rosenburg et al. (1982) who reported unchanged concentrations of pre-ovulatory LH surge in cows during heat stress. The reasons for these discrepancies are unclear, and it has been suggested by (Gilad et al. 1993) that these differences are related to pre-ovulatory oestradiol levels because the amplitude of tonic LH pulses and GnRH-induced pre-ovulatory plasma LH surge are decreased in cows with low plasma concentration of oestradiol, but not in cows with high plasma concentrations of oestradiol. Gilad et al. (1993), Lee (1993) have also reported that LH concentrations are decreased by heat stress and have drawn a conclusion that in summer, the dominant follicles develop in a low LH environment and these result in reduced oestradiol secretion from the dominant follicles leading to poor expression of oestrus, and hence, reduced fertility (Ahmed et al. 2015).

Duration of LH surges were significantly longer $P<$ 0.05 in cold dry season $(18.63 \pm 2.67 \mathrm{hr})$, followed by hot dry $(11.80 \pm 4.59 \mathrm{hr})$ and then raining season $(8.71 \pm 2.94 \mathrm{hr})$. There was no significant difference $P>0.05$ between hot dry season $(11.80 \pm 4.59 \mathrm{hr})$ and raining season $(8.71 \pm 2.94 \mathrm{hr})$. Which is inconsistent the work of (Lemon et al. 1975; Scheams et al. 1977, Mandan and Johnson, 1973) who reported that the duration of LH surge of $15.3 \mathrm{hr}$ in January in the Frisonne Francaise pie Naire breed of cow in temperate countries, also contradicts their findings in raining season that recorded longer duration of $21 \mathrm{hr}$ against the $8.7 \mathrm{hr}$ in the present study. The breed difference may explain the difference in the LH duration in the current study and other previous studies.

Table 6: Characteristics of pre ovulatory LH surge of zebu cows in cold dry, hot dry and raining season

\begin{tabular}{lllll}
\hline Season & $\boldsymbol{n}$ & $\begin{array}{l}\text { Time to peak } \\
\text { of } \mathbf{L H} \text { surge } \\
\text { (hr) }\end{array}$ & $\begin{array}{l}\text { Amplitude of } \\
\text { LH surge }(\mathbf{n g} / \\
\mathbf{m L})\end{array}$ & $\begin{array}{l}\text { Duration } \\
\text { of } \mathbf{L H} \text { surge } \\
\text { (hr) }\end{array}$ \\
\hline Cold dry & 12 & $38.38 \pm 2.29^{\mathrm{ad}}$ & $4.14 \pm 0.3^{\mathrm{bd}}$ & $18.63 \pm 2.67^{\mathrm{ac}}$ \\
Hot dry & 12 & $44.40 \pm 4.76^{\mathrm{ac}}$ & $4.18 \pm 0.86^{\mathrm{bd}}$ & $11.80 \pm 4.59^{\mathrm{ad}}$ \\
Raining & 12 & $53.86 \pm 5.37^{\mathrm{ac}}$ & $11.80 \pm 4.59^{\mathrm{ac}}$ & $8.71 \pm 2.94 \mathrm{~b}^{\mathrm{bd}}$ \\
\hline
\end{tabular}

Keys: $n=$ No of cows

$a=$ significantly higher $(P<0.05)$ along the row

$b=$ significantly lower $(P<0.05)$ along the row

$c=$ significantly higher $(P<0.05)$ along the column

$d=$ significantly lower $(P<0.05)$ along the column

\section{Effect of Heat Stress on Oestrus Expression and number of Mounting}

The results showed that oestrus duration was not significantly different $P>0.05$ among the study 
seasons cold dry season ( $2.2 \pm 0.2$ days), hot dry season (2.2 \pm 0.2 days) and raining season $(2.0 \pm 0.0$ days) respectively; Table 7 . Ostrus intensity was significantly higher $P<0.05$ in cold dry season $(7.6$ $\pm 0.93 / \mathrm{hr})$ followed by raining season $(6.2 \pm 1.28 / \mathrm{hr})$ and then hot dry season $(4.4 \pm 0.81 / \mathrm{hr})$ respectively. Which corroborate the reports of Ahmed et al. (2015), Pully et al. (2015) and Pennington et al. (1985), that mounting activity was reduced during hot weather when compared to cold weather leading to poor oestrus detection. Oestrus duration in the present study was the same in all seasons which is consistent with the report of Howel et al. (1994), but disagrees with the observation of (Gwadauskas et al. 1981 and Younas et al. 1993) who reported that heat stress reduced the duration of oestrus. We are associating this reduced mounting in heat stress season to the reduction of the proestrusoestradiol concentration that might have resulted to silence oestrus manifestation, because the cow may find it difficult to identify those cows in silence oestrus. The methods of heat detection (AM and PM role) used in the present study was not sufficient to capture all oestrus activities; some would have been missed out.

Table 7: Oestrus Duration and Number of Mounts of Zebu Cows during Cold Dry, Hot Dry and Raining Seasons

\begin{tabular}{llll}
\hline Season & Month & $\begin{array}{l}\text { Oestrus duration } \\
\text { (day) }\end{array}$ & $\begin{array}{l}\text { Number of } \\
\text { Mounts/day }\end{array}$ \\
\hline Cold dry & 4 & $2.2 \pm 0.2^{\mathrm{bc}}$ & $7.6 \pm 0.93^{\mathrm{ad}}$ \\
Hot dry & 3 & $2.2 \pm 0.2^{\mathrm{bc}}$ & $4.4 \pm 0.81^{\mathrm{bd}}$ \\
Raining & 5 & $2.0 \pm 0.0^{\mathrm{bc}}$ & $6.2 \pm 1.28^{\mathrm{ad}}$ \\
\hline
\end{tabular}

Keys: $n=$ No of cows

$a=$ significantly higher $(P<0.05)$ along the column

$b=$ significantly lower $(P<0.05)$ along the column

$c=$ significantly lower $(P<0.05)$ along the row

$d=$ significantly higher $(P<0.05)$ along the row

\section{CONCLUSION}

In conclusion, heat stress affect some reproductive indices of these cows by (i) increasing folliclesize without a corresponding increase inoestradiol concentrations, (ii) increasing or reducing preovulatory LH surge concentration, (iii) increasing progesterone concentration and (iv) reducing mounting activity. However, it is uncertain whether these changes can be related to the well-documented low breeding efficiency during the hot dry months of the year in tropical environment.

\section{ACKNOWLEDGMENTS}

We gratefully acknowledge the Tertiary Education Trust Fund (TET Fund) Nigeria for its financial support we received to execute this project. We also acknowledge the support of the Federal University of Agriculture, Makurdi Benue State Nigeria for providing facilities for us to carry out this research work to a successful conclusion. We thank The National Veterinary Research Institute Vom Nigeria for allowing us to carry out the Enzyme Linked Immunosorbent Assay technique in its laboratory. We are grateful to Dr. U. Husaini, Dr. Y.S. Wungak and Dr. A. Ebuji, for their technical assistance during the Laboratory work. We appreciate Dr. S. Ode and Dr. V. Ahur for helping us with the statistical analysis.

\section{REFERENCES}

Ahmed, A., Tiwari, R.P., Mishra, G.K., Jena, B., Dar, M.A. and Bhat, A.A. 2015. Effect of environmental heat stress on reproduction performance of dairy cow. A review: International Journal of Livestock Research, 5: 10-18.

Alves, B.G., Alves, K.A., Lucio, A.C., Martins, M.C., Silva, T.H. and Alves, B.G. 2014. Ovarian activity and oocyte quality associated with the biochemical profile of serum follicular fluid from Girolando dairy cows postpartum. Journal of Animal Reproduction Science, 146: 117-125.

Caraviello, D.Z., Weigel, K.A., Frick, P.M., Wiltbank, M.C., Florent, M.J., Cook, N.B., Nordlund, K.V.Z., Wald, N.R. and Rawson, C.L. 2006. Survey of management practices on reproductive performance of dairy cattle on large U. S. commercial farms. J. D. Sci., 89: 4723-4735.

Dawuda, P.M., Esievo, L.O., Molokwu, ECI. 1987. Determination of the optional time for artificial insemination (A.I.) in Nigerian zebu cattle. Nigerian Veterinary Journal, 16(1\&2): 23-25.

Dawuda, P.M., Eduvie, L.O., Esievo, K.A.N. and Molokwu, E. C.I. 1988. Interval between calving and first observable oestrus in post-partum Bunaji cows. British Veterinary Journal, 144: 258-261.

Du Preez, J.H. 2000. Ondersteppoort. Journal of Veterinary Research, 67: 263-371.

Du Preez, J.H., Giesecke, W.H. and Hattingh, P.J. 1990. Heat Stress in dairy cattle and other livestock under southern African conditions. I. Temperature-Humidity index mean values during the four main seasons. Onderstepoort. Journal Veterinary Research, 57: 77-87. 
Fisher, A.D., Morton, R., Dempsey, J.M.A., Henshal, J.M. and Hill, J.R. 2008. Evaluation of a new approach for the estimation of the time of the LH surge in dairy cow using vaginal temperature and electrodeless conductivity measurements. Theriogenology, 70: 1065-1074.

Fortune, J.E., Sirois, J., Turzillo, A.M. and Lavior, M. 1991. Follicles election in domestic ruminants. Journal of Reproduction Fertility Supplementation, 43: 187-198.

Galina, C.S., Orihuela, A. and Rubio, I. 1995. Reproductive physiology in zebu cattle, characteristics related to oestrous expression and performance of bulls utilized in natural mating. In: Congresso Brasileiro de Reprodução Animal, 11: 46-61.

Gilad, E., Meidan, R., Berman, A., Graber, Y. and Wolfenson, D. 1993. Effect of Heat stress on tonic and GnRH-induced gonodatropin secretion in relation to Concentration of oestradiol in plasma of cyclic cow. Journal of reproduction and Fertility, 99: 315-321.

Guather, D. 1996. The influence of season and shade on estrus behaviour, timing of pre-ovulatory LH surge and the pattern of progesterone secretion in Frisonne Francaisepie Naire and Creolerheifers in a tropical climate. Reproduction Nutrition Development, 26(3): 767-775.

Gwazedauskas, F.C., Thatcher, W.W., Kiddy, C.A., Pape, M.J. and Wilcox, C.J. 1981. Hormonal pattern during heat stress following PGF $2 \alpha$ - than salt induced luteal regression in heifers. Theriogenology; 16: 271-85.

Howell, J.L., Fuquay, J.W. and Smith, A.E. 1994. Corpus luteum growth and function in lactating Holstein cows during spring and summer. Journal of Dairy Science, 77: 735-9.

Kibler, H.H. 1964. Environmental physiology and shelter engineering. LXVII. Thermal effects of various temperature-humidity combinations of Holstein cattle as measured by eight physiological responses, Research Bulletin Missouri Agricultural Experiment station, pp. 862.

Khan, A., Dou, J., Wang, Y., Jiang, X., Zahoor, M., Luo, H. 2020.Evaluation of heat stress effects on cellular and transcriptional adaptation of bovine granulosa cells. Journal of Animal Science and Biotechnology, 11(25): 11-20.

Lemon, M., Pelletier, J., Saumande, J. and Signoret, J.P. 1970. Peripheral plasma concentrations of progesterone, estradiol-17 $\beta$ and luteinizing hormone around oestrus in cow. Journal Reproduction Fertility, 42: 137-140.

Lopez, G.F. 2003. Is fertility declining in dairy cattle?: A reproductive study in northwestern spain. Theriogenology, 60: 89-99.

Mattoni, M., Mukasa-Mugerwa, E., Cecchini, G. and Sovani, S. 1988. The reproductive performance of east African (Bos indicus) zebu cattle in Ethiopia: I. estrous cycle length, behavior and ovulation time. Theriogenology Worburn, 30(5): 961-971.

Madan, M.L. and Johnson, H.D.1973. Environmental heat effects on bovineluteinizing hormone. Journal of Dairy Science, 56: 1420-1423.
Nabenishi, H., Ohta, H., Nishimoto, T., Ashizawa, K. and Tsuzuki, Y. 2011. Effect of the temperature-humidity index on body temperature and conception rate of lactating dairy cows in south western Japan. Journal of Reproduction Development, 57: 450-456.

Orihuela, A., Galina, C.S., Escobar, J. and Riquelme E. 1983. Estrous behaviour following pro-staglandin $\mathrm{F}_{2} \alpha$ injection in Zebu cattle under continuous observation. Theriogenology, Worburn, 19(6): 795-809.

Piccione, G., Caola, G. and Refinetii, R. 2003. Daily and oestrus rhythmicity of body temperature in domestic cattle. Biomeical Central Physiology, 3: 7.

Plasse, D., Warnick, A.C. and Koger, M. 1970. Reproductive behavior of Bos indicus females in a subtropical environment: IV. Length of estrous cycle, length of estrus, time of ovulation, fertilization and embryo survival in grade Brahman heifers. Journal of Animal Science, Champaign, 30(1): 63-72.

Pinheiro, O.L., Barros, C.M., Figueiredo, R.A., Valle, E.R., Encarnação, R.O. and Padovani, C.R. 1998. Estrous behavior and the estrus-to-ovulation interval in nelore cattle (Bos Taurus Indicus) with natural estrus or estrus induced with prostaglandin $\mathrm{F}_{2}$ or norgestomet and estradiol valerate. Theriogenology, Worburn, 49(3): 667-681.

Pathiraja, N., Oyedipe, E.O., Dawuda, P.M., Chaudhri, S.R. 1988. Intensive breeding schemes in zubu cattle under field condition in Nigeria. World Animal Review, 65: 55-57.

Pully, S.L., Keisler, D.H. and Stevenson, S. 2015. Concentration of luteinizing hormone and ovulatory response in dairy cows before timed artificial insemination. Journal of Dairy Science, 98: 6188-6201.

Pennington, J.A., Albertight, J.L., Diekman, M.A. and Callahan, C.J. 1985. Sexual activity of Holstein cows: seasonal effects. Journal of Dairy Science, 68: 2023-30.

Roth, Z., Arav A., Zeron, Y., Braw-Tal. R. and Wolfenson, D. 2001a. Improvement of quality of oocytes collected in the autumn by enhanced removal of impaired follicles from previously heat stressed cows. Reproduction, 122: 737-744.

Roth, Z., Meidan, R., Shaham-Albalancy, A., Braw-Tal, R., and Wolfenson, D. 2001b. Animal Reproduction Science, 121: 745-751.

Rosenberg, M., Herz, Z., Davison, M. and Folman, J. 1977. Seasonal variation in post-partum plasma progesterone levels and conception in primiparous and multiparous dairy cows. Journal of Reproduction and Fertility, 51: 363-367

Ronche, J.F. and Diskin, M.G. 2000. Resumption of reproductive activity in the early postpartum period of cows. In: Diskin M.G., editor, Fertility in the high-producing dairy cow.Vol. 26. BSAS Edinburgh, Occational Publication; pp. 133-45.

Schams, D., Schallenberger, E., Hoffman, B. and Kerg, H. 1977. The estrous cycle of the cow: hormonal parameters and time relationships concerning oestrus, ovulation and electrical resistance of the vaginal mucus. Actetectural Endocrinology, 86: 180-192.

Shehab-El-Deen, M.A., Leroy, J.L., Fadel, M.S., Saleh, S.Y., Maes, D. and Van Soom, A. 2010. Biochemical changes 
in the follicular fluid of the dominant follicle of high producing dairy cows exposed to heat stress early postpartum. Animal Reproduction Science, 17: 189-200.

Timi, E.O. and Tor, T. 2016. The changing rainfall pattern and its implication for flood frequency in Makurdi Northern Nigeria. Journal of Apply Science, Environmental Management, 10(3): 97-102.

VohJr, A.A., Dawuda, P.M. and Rekwot, P.I. 1989. Gestation length of artificially inseminated zubu cows and their Friesian crosses. Journal of Animal Reproduction Science, 9(2): 109-117.

Wakayo, B.U., Brar, P.S. and Prabhakar, S. 2015. Review on mechanisms of dairy summer infertility and implications for hormonal intervention. OpeVeterinary Journal, 5: 6- 10.

Wilson, S.J., Marion, R.S., Spiers, D.E., Keisler, D.H, Lucy, M.C. 1998. Effect of controlled heat stress on ovarian function in dairy cattle: 1 . Lactating cows. Journal of Dairy Science, 1: 2124-2131.

Wolfenson, D., Law, B.J., Thatcher, W.W., Graber, Y. and Meidan, R. 1997. Seasonal and acute heat stress effects on steroid production by dominant follicles in cows. Animal Reproduction Science, 47: 9-19.

Wolfenson, D., Thatcher, W.W., Badinga, L., Savio, J.D., Meidan, R., Lew, B.J., Braw- Tal, R. and Berman, A. 1991. Effect of heat stress on follicular development during oestrous cycle in Lactating Dairy cow. Biology of Reproduction, 52: 1109-1113.
Wolfenson, D., Thatcher, W.W., Badinga, L., Savio, J.D., Meidan, R., Lew, B.J., Braw- Tal, R. and Berman, A. 1995. Effect of heat stress on follicular development during oestrous cycle in Lactating Dairy cow. Biology of Reproduction, 52: 1109-1113.

Wolfenson, D., Kaim, M., Rosemberg, M. 1994. Conception rate of cows supplemented with progesterone postinsemination in the summer. Journal of Animal Science; 72(Suppl.1), 280.

Younas, M., Fuquay, J.W., Smith, E.A.E. and Moore, A.B. 1993. Oestrus and endocrine responses of lactating Holsteins to forced ventilation during summer. Journal of Dairy Science; 76: 430-434.

Zakari, A.Y., Molokwu, E.C.I., Osorio, D.I.K. 1981. Effect of season on the oestrous cycle of cows (Bos indicus) indigenous to northern Nigeria. The Veterinary Record. [S.1.]; 109:(11): 213-215. 
